\title{
Coming to Terms with the Fleeting Post-Zionist Moment
}

\author{
Yehonatan Alsheh, Wilfrid Laurier University
}

Ilan Pappe, The Idea of Israel: A History of Power and Knowledge, (London: Verso, 2014). 346 pp. \$26.95 Hardback.

Uri Ram, Israeli Nationalism: Social Conflicts and the Politics of Knowledge, (New York and London: Routledge, 2011) 171 pp. \$136.00 Hardback.

\section{Laurence J. Silberstein, The Post Zionism Debates: Knowledge and Power in Israeli}

Culture, (New York and London: Routledge, 1999). 275 pp. \$162.00 Hardback.

What is at stake in writing - and critically reading - a history of post-Zionism? The highly contemporary nature of the subject matter - at its core it is an intellectual history of an ideological mood among certain Israeli elites during the 1990 s - makes every pretense of retrospect almost too tentative to be taken seriously. The evident fleeting of that mood, and the bitter understanding that this apparently was all that it ever was - a fleeting mood - tempts one to wonder if the subject at all merits this kind of attention. If it does, it surely requires a detailed explanation of its wider significance - the general phenomena illustrated by it.

Attempts to analyze and narrate the rise and (at least for now) fall of post-Zionism are of interest to historians because post-Zionism has been first and foremost a historiographical phenomenon. The post-Zionists debates accentuate tensions between academic historiography and collective memory; the mutual dependency of political ideologies and historiography; the uses and abuses of history in the public sphere; and more specifically the benefits and costs of genuine public interest in historiographical debates. Post-Zionism nicely showcases how history writing and rewriting are implicated in political circumstances and ideological reconfigurations.

In April 1998, the Economist titled a special supplement marking fifty years for the establishment of Israel, "After Zionism." And at the time, this seemed to be where things were headed. Indeed, as far as the Economist's unfaltering liberal point of view was concerned, this was where things should have gone. The argument being that Zionism had done its job - the Zionist enterprise (to literally translate the Hebrew expression) had gloriously succeeded in establishing a prosperous Jewish nation state. By its fiftieth anniversary however, it 
seemed that if Israel was to continue flourishing - transcending all the obstacles and threats that still lied ahead - Zionism must give way to a new ideological configuration. And as is usually the case on the pages of the Economist, this argument was both prescriptive and descriptive - this was not only what should happen but also what was already, unavoidably, happening.

The idea that Zionism was good - or at least suitable or beneficial - for its time, but no longer, meaningfully transcends the century old opposition between Zionist and anti-Zionists. Neither eternally cheering for the Zionist cause nor categorically resisting it, post-Zionism tried to open a previously unarticulated third option or horizon of options. There was of course an entire spectrum of ways and means to do that. Some post-Zionists, in a way similar to the position expressed by the Economist, adopted a "two cheers" understanding of Zionism and its accomplishments, calling for a mature (yet also rejuvenating) soul searching process - confronting past injustices and wrongdoings so as to build a more inclusive and just Israeli society.

Others preferred a more defamatory interpretation of Zionist history, understanding it as colonial in nature, oppressive, discriminatory and dispossessing in conduct. Yet unlike classic anti-Zionism, understanding what Zionism really was, was understood as an enlightening reconsideration, made possible by a new historical constellation. Arguably, it was previously impossible for Jewish Israelis to see Zionism for what it really was.

What was that new historical constellation? On the intellectual academic plain it was Lyotard's postmodern condition; Habermas' post-national constellation; or Rorty's celebration of irony, contingency and solidarity. ${ }^{2}$ On the political-economic plain there was a complex constellation of institutional restructuring, regulatory reforms and technological innovations termed at the time globalization. On the geopolitical plain the cold war ended and locally, the IsraeliPalestinian conflict and with it and through it the wider Jewish-Arab conflict seemed on the verge of a peaceful solution.

By the first decade of the new century, things begun to fall apart. Maintaining an incredulous stance toward all ideologies did not prove itself as liberating and creative as hoped for. At the same time the widening inequalities and new strategies of global exploitation and dispossession made globalization more controversial and questionable (though no less triumphant in terms of its continuous expansion and entrenchment). The high hopes for the coming peace were shattered with the eruption of the second Intifada in response to Israel's incessant expansion of Jewish settlements in the West Bank. Israel's wars with the Hezbollah in Lebanon and the Hamas in Gaza soon followed. It is in this regard all too tempting to collapse the intellectual history of the post-Zionist moment into yet another attempt at explaining, or at least ascribing blame for, the collapse of the Oslo process. 
I begin this review article by anecdotally suggesting the similarities between the post-Zionist moment in Israel and the demise of Afrikaner nationalism in South Africa, only a few years before the process begun in Israel. While the three books reviewed do not attempt to place and interpret post-Zionism in a comparative framework, I suggest that only by abstracting the history of the post-Zionist mood from its Israeli context and rephrasing it in general terms, would we be able to understand it and the meaning of its regrettable trajectory. It is, I believe, what is at stake when writing a history of post-Zionism, as oppose to merely reducing it to an epiphenomenon of the Israeli-Palestinian conflict.

In the second part of the article I outline the various kinds of postZionist scholarship as read in the three reviewed studies. In the third part of the article I turn to the problem of neo-Zionism, questioning the way this latest ideological turn in Israel is understood by Uri Ram and Ilan Pappe, suggesting that it might be better for the purpose of an intellectual history of post-Zionism to understand neo-Zionism as part of the post-Zionist phenomenon.

\section{The Lynching of Van Jaarsveld}

On March 28, 1979, at the senate hall of the University of South Africa (UNISA) in the city of Potchefstroom, the prominent Afrikaner historian, Professor Floors Van Jaarsveld from Pretoria University, delivered a public talk. He challenged the celebration of the 'Day of the Vow'. A day held sacrosanct by Afrikaner nationalism in commemoration of the 1838 "Battle of Blood River." Where, 471 Voortrekkers, the pioneering forefathers of the Afrikaner nation, miraculously (as the official version at the time held) decimated the Zulu forces, killing more than 3000 warriors.

Jaarsveld questioned the morality of forcing a day of man-made Sabbath on all the populations in South Africa. The majority of which trivially identify with those defeated. If not morally wrong it was politically imprudent. He pointed out that the day was only sanctified five decades after the event itself. But above all, Jaarsveld hinted that divine intervention might have been more indirect than is commonly assumed, given that the Voortrekkers had a canon at their disposal. ${ }^{3}$

Jaarsveld debunked the Afrikaner national myth of Blood River. As he saw it, a rather mundane clash between unequal forces on the colonial frontier was reframed as a biblical scene: the Voortrekkers being the people of Israel and the Zulus one of the peoples of Canaan. While he was lecturing, forty-seven thugs in suits marched into the hall. The men, all members of the AWB (Afrikaner Weerstandsbeweging: Afrikaner Resistance Movement), a radical separatist movement, unceremoniously climbed to the stage and begun pouring tar 
and feathers over the shocked and silent Jaarsveld. ${ }^{4}$

The lynching of Jaarsveld won the AWB the public attention they were seeking. While the government condemned the violent nature of the act, mainstream Afrikaners deemed the allegedly healthy, patriotic sentiment behind it, understandable if not salutary. This public display of popular rage against Jaarsveld's iconoclastic scholarship led to the removal of Jaarsveld's history textbooks from the school system's curriculum and to major publishers turning their backs on him as well as taking his previous books off the shelves.

A decade and a half later, however, Jaarsveld's views became commonplace, among most Afrikaner populations. "The day of the vow," was remade in 1994 into the "day of reconciliation." Afrikaner nationalism became all but extinct, ${ }^{5}$ and its historiography rejected as the outdated ideology of an infamous regime. For example, 2002 marked a hundred years to the South African war of 1899-1902, which under its previous name, the Anglo-Boer war, functioned as a constitutive national trauma in Afrikaner collective memory. The retelling of the story of the war, reviving in it the interlocking stories of all the populations of South Africa - first and foremost the story of the black concentration camps exemplifies the dissolution of Afrikaner nationalism into the nation building process of the new South African nation. ${ }^{6}$

This abrupt ideological transformation has been recently suggested as a new foundational myth for a new and post-national configuration of Afrikaner identity, Afrikaans political ethnicity. ${ }^{7}$ Supposedly, Afrikaners have been exceptional in their collective willingness to renounce their previously-held-as-sacred national history and begin a torturous process of writing an essentially contested new national history. ${ }^{8}$ Afrikaner nationalism has, according to those so arguing, proved unique in its ability to voluntarily, without being defeated in any narrow sense of the word, dissolve into a new nation-building project. ${ }^{9}$

The project of reconciling the new South African nation in itself speaks in terms of the "South African miracle" in reference to the ideological transformation of South Africa. This, however, is merely an expression of the construction of a new foundational myth for what is at the end of the day a new nation. The aforementioned self-congratulatory claims of those currently advocating the resurrection of an Afrikaans political ethnicity, are also nothing but myth making gestures. The peaceful dismantling of Afrikaner nationalism in the context of the democratization of South Africa in the early 1990s cannot be productively explained by reference to an alleged exceptionality of the Afrikaners, or divine miracle making for that matter.

Some students of the democratization of South Africa, have identified two distinct phases in the democratization of South Africa. The first, consisting of de-nationalization which was then followed by a second phase of re-nationalization. Both processes were not only ideological, but in fact first and foremost institutional and economic, i.e. a vast privatization of state assets and services 
that was then followed by a rebuilding of the state as, once again, the main employer, income provider and allocator of resources. ${ }^{10}$

It is the process of de-nationalization, abstracted from the peculiarities of the South African historical circumstances that may best serve us as a theoretical framework for a comparative and critical understanding of post-Zionism. It is, I believe, what post-Zionism has been - an attempt at a de-nationalization of Israeli society. As in South Africa, it was also soon followed by a re-nationalization. Albeit, not of the kind hoped for - in some of the cases envisioned - by post-Zionists writers.

The re-nationalization of South Africa, was also, though not at all a resurrection of Afrikaner nationalism, a disappointment as far as many South African intellectuals are concerned. They are critical of what they believe is an African nationalism from which whites, Indians, coloureds and interracials are (mostly informally) excluded in different ways and to various degrees. De-nationalization, though defamatory and negative in nature is in fact a hopeful, almost euphoric phase. Re-nationalization is hence the unavoidably disappointing and frustrating scaling back of hopes. This said, in the same way as de-nationalizations vary so do re-nationalizations - some far more disappointing then others.

Interestingly, the theoretical and comparative study of nationalism, has so far dedicated far greater attention to Zionism and its loud discontents than to the uncommon historical trajectory of Afrikaner nationalism. Some comparative analyses of those two national movements have been published over the years, mostly in the context of the application of the apartheid paradigm to IsraelPalestine. ${ }^{11}$ However, so far the demise of Afrikaner nationalism and postZionism have not been comparatively studied.

In more general terms, we usually ask more about how nationalisms are born and mature, then about how some nationalisms happen to perish. While the field of genocide studies (in itself intimately connected with post-Zionism) asks: "how nations die?" and even: "how do nations die even when their members do not physically die?"12 So far we have not properly asked: How do nationalism die? Given the intensity of the classic debate between those who stress the endurance and longevity of nations and those for whom nationalism is a rather recent and (as such presumably) a fleeting phenomenon, ${ }^{13}$ it is surprising how little attention has been so far given to the few cases in which nationalisms have indeed found their way to history's recycle bin.

\section{The Space Clearing Gesture}

In 1995, the historian Ilan Pappe, wrote that the post-Zionist debate: "reflects not only an academic dispute, but also an identity crisis of a society that stands on the threshold of a period of peace, in which the national consensus, 
previously built upon threats to survival and security problems, clears a space for a debate across the society and its culture" (Silberstein, 2).

Laurence J. Silberstein, a professor of Jewish studies, quoted Pappe in the introduction to his 1999 book, The Post Zionism Debates: Knowledge and Power in Israeli Culture. Writing at what in retrospect is said to be the zenith of the postZionist moment, Silberstein approvingly identifies in Pappe's quote the philosopher Kwame Anthony Appiah's concept of "a space clearing gesture,"14 suggesting that post-Zionism is "clearing space for previously silenced voices and for alternatives to the dominant Zionist discourse" (Silberstein, 4).

However, though Silberstein describes the post-Zionists as engaged in a space clearing gesture, in Pappe's quote, it is actually the national consensus that is clearing the space, not the post-Zionists. They, according to Pappe, are engaged in the debate made possible by the clearing of the space. This of course would hardly merit attention, if the national consensus did not begin to close the space, it was formerly clearing, about a year after the publication of Silberstein's book.

Silberstein's book, the seminal English language monograph about post-Zionism until the publication of the sociologist Uri Ram's 2011 book, Israeli Nationalism: Social Conflicts and the Politics of Knowledge, well documents the smug spirit of post-Zionism between the years 1994 and 2000. Silberstein's misreading with regard to who exactly was clearing the space was, I believe, not merely coincidental. Rather, it is symptomatic of the way many post-Zionists were tempted at the time to forget or disregard the fleeting conditions enabling their enterprise. $^{15}$

Leaving the question of who was at the end of the day the author of the space clearing gesture, aside for the time being, what substantially was that gesture, i.e. what was post-Zionism? Ram identifies four distinct perspectives or frameworks in which post Zionists have understood post-Zionism. Though he, for some reason, insists on labeling them all with names that start with the prefix "post": post-ideological post-Zionism; post-Marxist post-Zionism; postmodern post-Zionism and postcolonial post-Zionism, the typology in itself is a useful way of mapping the phenomenon.

The first one being the post-ideological tradition, in which the family of forms Zionism assumed since the late nineteenth century and up until the 1970s is seen as characteristic of the nation-building phase of emerging states. According to this approach, post-Zionism is merely a normal transition to the kind of inclusive, civic, and banal nationalism, characteristic of mature liberal states. Arguably, mature conventional expressions of peoplehood, can and in fact should entertain revisionist accounts of their respective national myths, as well as work-through previously silenced and denied episodes of wrongdoing and inequity. 
Silberstein's "space clearing gesture" consist in this case of letting go of a rigid and idealized conception of the nation and its history. This conception is, gradually and by means of a calm and informed public debate, replaced by a well-rounded understanding of the nation as truly a "nation among nations," and as such, equally imperfect. The nation, however, is also well capable of owning up to its past transgressions. This process of unearthing embarrassing chapters in the nation's history; negotiating the nation's identity by means of apologies and compensations; and practicing meaningful reconciliation, is imagined as a process of maturation. As such it is imagined in the end of the day as affirmative and self-asserting.

This is a thoroughly liberal understanding of post-Zionism, premised on the ideals of universal human rights and an international rule of law. ${ }^{16} \mathrm{It}$ evokes Mazzini's ideal of the nation as the intermediary entity through which individuals take part in the greater whole of humanity. ${ }^{17}$ Assuming nationalism as essentially benign, it aims to combat the malignant and predatory excesses of nationalism, which are understood and excused as "growing pains" - the forgivable diseases of the infancy of nations.

A second post-Zionist framework Ram terms, "post Marxist." It understands post-Zionism as symptomatic of the macro-level social and economic transformations Israel has undergone since the 1980s - the various new forms of organizing production and the markets, commonly termed globalization. According to Ram:

This transition disrupts the balance of power between capital labor and state which prevailed in the corporatist (Fordist) state, and it ushers in an unbalanced power structure under capital tutelage. Two "non-economic" results of this major shift of the social regime are the rise of inequality in the distribution of income; and a trend of fragmentation of the population into identity groups (Ram, 135).

As opposed to the post-ideological variety of post-Zionism, this framework does not suggest post-Zionism to be a positive manifestation of progress or maturation. It is no wonder in this regard that this approach also informs the Zionist historian Daniel Gutwein. Gutwein has been habitually deploring postZionism as the privatization of collective memory and identity and as such an accomplice in the destruction of the Zionist developmental welfare state. ${ }^{18}$ PostMarxist post-Zionists, to use Ram's terminology, argue that Gutwein disregard the fact that the Zionist developmental welfare state was never universal but only a Jewish developmental welfare state, was primarily benefitting Jewish populations. Beyond the discriminatory nature of the Zionist developmental welfare state, critics of Gutwein point out the uncompensated nationalization of Palestinian property after 1948 (and again though in a different way after 1967) as well as the exploitation of Palestinian labour from the west bank and the Gaza strip until 1991. 
In the case of Ram's post-Marxist post-Zionism, it is the restructuring of the economy that is responsible for Silberstein's space clearing gesture. Zionist ideology and rhetoric became identified with the national labour union, the national industries and in general with state interference in the economy. Both were depicted as outdated, corrupt, inefficient and grotesque. The sets of beliefs underpinning both Zionist ideology and the corporatist state were exposed as embarrassing fabrications. Above all, it was argued that the inefficiencies of the colossus public sector, just like the childish fairy tales of Zionism, are dangerously unsustainable - a precarious illusion on the verge of bursting, regardless of how fond of it people might personally be.

Ram terms a third post-Zionist framework, "postmodern." PostZionism is not, according to this approach, a banal - and benign - symptom of maturation, but a productive incredulity towards the Zionist meta-narrative. It is a specific case of an assumed generalized disbelief in modernity's meta-narratives - Lyotard's postmodernist condition. The intellectual work performed under the banner of post-Zionism aims in this case to locally liberate multitudes of identities and identification practices from the exclusionary, essentialising and homogenising effects of Zionism.

Though this is only one variation of post-Zionism, and the one least characteristic of post-Zionist historians, it is the one most commonly identified with the phenomenon as a whole. Unlike all other variations, postmodern postZionism does not present a historical argument for its own emergence - it does not explain why it appeared and prospered (let alone why is it a positive thing that it did) at the time that it did.

The "space clearing gesture," in this case, consists of acknowledging the ways and methods in which what is in origin plural, hybrid and unstable is stabilized, routinized, homogenised and purified. Both coerced and seduced into the Zionist regime of the normal, diasporic identity sustaining practices (among which languages); communal structures; forms of knowledge and authority; micro-practices of resistance and temporary suspension of oppression; alternative traditions; and local narratives and ways of ordering things, disappeared, demonized and ridiculed.

Ram however, positions, next to the above, mostly Foucauldian understanding of postmodern post-Zionism, an approach he calls Habermasian or citizenship oriented postmodern post-Zionism. This is Ram's personal favoured variation and it is catalogued as postmodern, mostly because of Ram's personal (and idiosyncratic) attachment to this concept. As it was Ram who originally suggested the term post-Zionism in 1993, this appears to also be the reason why, given the prefix 'post', post-Zionism ended up overtly-associated with postmodernism. 
Premised on Brubaker's classic distinction between ethnic and territorial nationalism, ${ }^{19}$ this framework understands post-Zionism as the attempt to decouple Israeli nationalism from the Jewish or any other ethnically defined communal identity. According to Ram:

This type of nationalism based on a present common framework of life, rather than on past myth, may overcome the unresolved tension between the Jewish component in Israeli identity, which may turn into a matter of private or sub-communal affiliation, and the democratic component of Israeli identity, which must turn into the state's constitutional basis (Ram, 133).

The fourth post-Zionist approach according to Ram is termed postcolonial, and understands post-Zionism as part of the ongoing struggle against colonialism in all its expressions and manifestations. Zionism is best understood as a particular expression of European colonialism - a colonialism of a special nature. Post-Zionism as a postcolonial phenomenon aims to uncover and contest all the ways and sites in which non-Europeans (whether Palestinian or Jews from Muslim countries) are disempowered, marginalised, discriminated and excluded.

Typologically wise, I think Silberstein is right to catalogue postmodern and postcolonial post-Zionism together (Silberstein, chapter 6). The similarities and commonalities between postmodern and postcolonial post-Zionism strike me as far greater than those Ram seems to find between postmodern postZionism and his own Habermasian post-Zionism, which should in fact constitute a category in its own right.

The space clearing gesture in the case of post-colonial post-Zionism is brought by the "return of the repressed." The remnants of the Palestinian past, though systematically demolished, nevertheless begun haunting the grandchildren of those who fought in 1948. For example, the abandoned quarter of Wadi Salib at the very heart of Haifa, a unique case of a major Palestinian neighborhood left in its abandoned state for five decades. ${ }^{20}$ There was a growing discontent with the aridness of the Zionist account of all that was before the establishment of Israel. The declassification of documents from 1948, in British and Israeli archives. Yet, most of all it was the eruption of the Intifada (the wide spread popular revolt of Palestinians in the West Bank and Gaza in 1987), which most Jewish Israelis experienced as surprising and inexplicable.

Postcolonial post-Zionism, is the most productive approach, especially from a historiographical perspective since it re-embeds Zionism in wider colonial phenomena. Pappe, originally identifying himself with this variation of postZionism, challenged in his work the existing belief that Britain opposed the independence of Israel and was mobilized, at least partially motivated by the characteristic anti-Semitism of its upper class, against Israel. Showing that Britain was mostly neutral, and when biased, backing the Israeli rather than the Palestinian side, Pappe stressed the indifference of Britain to the Nakba. Looked 
at from the perspective of Britain's indifference to other, greater and far more murderous, mass expulsions of populations taking place in Europe and Asia at the same time, this should hardly be surprising.

However, Israel and the Zionist colonisation campaign preceding its establishment, was not and cannot be understood as merely part of the British Empire. Postcolonial post-Zionism's contribution to the wider field of postcolonial studies, lies in fact in the way it forces one to disaggregate and further develop the simple categories of indigenous, settler and empire. Adding the important category of refugee, it introduces the dynamic of refugee populations (first the Jews, later the Palestinians) whose problem is both framed and (insufficiently) solved by international organisations and interested states. The international decision to solve Europe's Jewish problem by means of a Jewish state on part of Palestine as well as the decision to perpetuate for four generations the Palestinian refugees problem, is in this regard, part of colonial history.

Pappe, however, though fleshing out in his research most of the above drama, prefers to revert in the last decade back to classic anti-Zionist frameworks. Disillusioned by the collapse of post-Zionism after 2000, Pappe prefers narrating the story in a way that clearly specifies a victim and a villain (even if a complex villain which one can easily identify with). In this regard his story of post-Zionism is personal, hagiographic when describing the courageous pioneering efforts of individuals before the 1980s, and far more political than theoretic in its guiding passion.

\section{A Postmortem of the Possibly Dead}

In his 2014 book, The Idea of Israel: A History, Pappe argues that "more than anything else post-Zionism was a mood [...] when it changed as moods do, it could easily be declared dead, which is what one Israeli journalist declared in Haaretz in September 2001. Alas at least from the perspective of this writer [Pappe], it was. This book is in many ways post-Zionism's post mortem" (Pappe, 132).

However, putting forward a proper postmortem of post-Zionism, that is an examination of the dead body so as to ascertain the cause of the death, might be a greater task then Pappe allows for in his book. To begin with, is it at all true that post-Zionism is - to the extent that such metaphoric language is helpful - dead?

On the one hand, the historian Shlomo Sand's 2008 (in Hebrew, 2009 in English) best seller The Invention of the Jewish People, stirring much public controversy both in Israel and in Europe (and to a lesser extent in North America), seems to indicate that post-Zionism did not die in $2000 .{ }^{21}$ The philosophers Adi Ophir and Ariella Azoulay's 2008 study The One State Condition and Azoulay's 2009 photographic history of the Nakba, failed to attract the attention these works deserve. $^{22}$ However, Ophir's project: the Lexicon for Political Theory, 
launched in 2010, has been a highly productive site of post-Zionist thinking and writing, attracting more scholarly and public attention than any other academic activity in Hebrew during the past five years. ${ }^{23}$

In late 2014, the Ben Gurion Research Institute for the Study of Israel and Zionism published the historian Dafna Hirsch's comprehensive study ' $W$ e are Here to Bring the West' - Hygiene Education and Culture Building in the Jewish Society of Mandate Palestine. ${ }^{24}$ Nuanced and critical rather than polemical, Hirsch's work exemplifies mature and confident post-Zionist historiography at its best, published by one of the strongholds of Zionist scholarship. Interestingly, Hirsch cautioned in a recent interview, that framing Zionism as colonialism is not wrong as much as it is an oversimplification of a complex and tellingly convoluted story. $^{25}$

On the other hand, post-Zionism did change dramatically after the year 2000. From a triumphant spirit of the era, sweeping the Humanities and even more so the Social Sciences faculties in Israeli Academia, post-Zionism became by the first decade of the new millennium, a demonized heresy. Post-Zionist discourse, previously celebrated as robust and disenchanted, was now widely denigrated as flippancy - nothing more than a few privileged intellectuals always talking as if the joke about Zionism has already been made. Now however, more and more people (among which donours) found themselves wondering, why exactly is it so grotesquely absurd to be a Zionist?

Ram, acknowledging that post-Zionism has indeed lost its trendy glitter in the eyes of those attentive to this particular dimension of intellectual production, nevertheless argues that:

While in political terms post-Zionism is not at its peak at present, this is not necessarily the case with regard to the impact of post-Zionism on Israeli culture, especially the elite culture. In this regard the talk of "decline and fall" is in all probability short-sighted. Post-Zionism seems to have been diffused rather deep into the public consciousness. Hence, the circumstantial political state of post-Zionism should not be confused with its structural position (Ram, 126).

For Ram, it is a mistake to judge post-Zionism "in the positivistic terms of popular spread or of political effect" (Ram, 126). Being an emergent counterhegemonic trend, post-Zionism's true achievement according to Ram, is discursive. That is, its achievement is the very creation of formerly non-existing horizons, positions, options, questions, concepts, and problematisations. Though it was only for less than a decade that post-Zionism appeared to be on the verge of dethroning Zionism as Israel's hegemonic ideology, its very emergence - a previously non-existent family of third options transcending the Zionist-anti-Zionist opposition - cannot be undone. Not so easily in any case. 
Ram's faith in the irreversibility of post-Zionism, invites on a certain level a symptomatic rather than substantive reading. Insisting that what empirically appears to be dead is in fact immortal and hence only moved to transcendent pastures "in critical theory terms, post-Zionism is a concept of both immanence - tapping undercurrents; and transcendence - pointing towards an exogenous normative horizon," (Ram, 126) is an ancient and all too familiar move. However, one will be wrong to dismiss Ram's argument as merely typical of the aftermath of intolerable defeats.

From Ram's perspective, post-Zionism was never really smug, and while Silberstein might have misread Pappe, he was nevertheless right in describing the post-Zionists as those who clear the space. For him, post-Zionism was never fully dependent on - reducible to - external conditions. Post-Zionism, though conditioned and constrained by political circumstances was never directly stirred by them and cannot be exhaustively reduced to them. Post-Zionism as a scholarly and cultural phenomenon should be conceptualised as having its own agency and as such only structurally coupled with the political system, both mutually (though not equally) conditioning and constraining each other.

Unlike Ram, Pappe, who though writing after the publication of Ram's book (the Hebrew version was already published in 2006) does not mention it, 26 thinks that post-Zionism failed in its search for an alternative to Zionism. This resulted in a return of most of those formerly identified as post-Zionists "to the ideology's warm embrace” (Pappe, 8); while a few (Pappe among them) either turned or returned to anti-Zionism. In other words, Pappe sees post-Zionism as a failed attempt to transcend the Zionist - anti-Zionist opposition by means of opening up a third possibility. For him, though such an alternative was clearly and loudly aspired, it never actually materialised. The violently intolerant public atmosphere in Israel during the 2014 war in Gaza (termed by Israel operation "Protective Edge") as well as the bluntly racist and inflammatory rhetoric that helped Netanyahu win the 2015 elections, appear to further validate Pappe's verdict.

Yet, Pappe says with reference to the shift of political temperament in Israel since the new millennium: "[t]hus did the pendulum swing from Zionism to post-Zionism thence to neo-Zionism” (8). This misapplication of the metaphor of a pendulum is, I believe, telling. While describing a swinging pendulum, Pappe is actually speaking of a movement between three distinct positions (Zionism, post-Zionism, neo-Zionism), not an oscillation between two positions. Pappe remains ambivalent and partial to the category of neo-Zionism, consistently treating it as a return or a re-entrenchment of Zionism. This in turn begs the question: why apply the category in the first place?

And indeed Pappe's last two chapters (and the epilogue), dedicated to neo-Zionism, are the least insightful part of his study. Understandably so, to be sure, as not enough time has yet passed and Pappe, being a historian, does not 
pretend nor claim to have sufficient perspective on the subject matter. The relative scarcity of research on this most recent development in the Israeli ideological landscape, renders any scholarly reference to neo-Zionism as merely a pioneering gesture. ${ }^{27}$

The problem is one of definition: what does one mean exactly by neoZionism? How does neo-Zionism differ from Zionism and why is there at all a need for such a category?

While post-Zionism was a term suggested by Ram in a volume he edited in 1993, Israeli Society: Critical Perspectives, ${ }^{28}$ and was quickly embraced by postZionists as well as the media, this is not the case with neo-Zionism. The term was (arguably) coined in 2010 by a key neo-Zionist activist, Ronen Shoval, head of the Im Tirtzu NGO, whose ongoing highly effective campaigns against an alleged post-Zionist hegemony in Israeli academia have significantly affected academic freedom in Israel. ${ }^{29}$ However, the term is currently almost exclusively used by post-Zionists (and to a lesser extent anti-Zionist) critics of this ideological turn. Zionist critics of neo-Zionism prefer to term it "right-wing postZionism" or "Settlers' post-Zionism" (Ram, 114).

As the term neo-Zionism suggests Zionism reconstituted after the post-Zionist challenge, it seems only attractive to those who have an interest in framing post-Zionism as meaningful enough so as to justify registering its occurrence in the name of its triumphant opponent. It is in this regard not surprising that other than post-Zionists, only people like Shoval, who made it his life mission to salvage Israel from the malignant havoc of post-Zionism, are in need of a term such neo-Zionism. And yet, if one observes the current Israeli ideological landscape it does seem that for the past two decades there has been an explicit ideological debate between rather classic Zionist stances and what will qualify as neo-Zionist ones. ${ }^{30}$ In many ways, the Zionist - post-Zionist debates of the 1990 s gave way in the twenty-first century to what is essentially a Zionist - neoZionist controversy.

Ram delineates: "three main historical meta-narratives that compete over the re-designation of Israeli identity: the old national meta-narrative; and the two new counter-meta-narratives of neo-Zionism-an exclusionary ethnonationalist trend; and of post-Zionism — an inclusionary (but class biased) liberal trend" (Ram, 4). Arguing that: "[i]n face of the unresolved strain within mainstream Zionism (Israel as Jewish and democratic) and the ethnic racism of Jewish neo-Zionism (Israel as a Jewish state), the concept of post-Zionism (Israel as a democratic state) emerged in the 1990 s as a democratic liberal alternative" (Ram, 112).

In other words, at the heart of Zionism lies an unresolvable paradox: it is somehow equally democratic and Jewish. Though a democracy, the right of self-determination and in fact any practice of collective rights, is unique to the Jewish people and denied to Israel's non-Jewish citizens (let alone the 4 million 
non-citizens), even though they cannot assimilate into the Jewish people. While a democracy, the state does not promote the interest of all the populations under its sovereignty, but only those of the Jewish people, though only half of which have Israeli citizenship and of its citizens $20 \%$ (and up to $40 \%$ of the entire population) are not and cannot become Jewish.

Zionism denies that this is a paradox, or in any case that it is an unsustainable one. Post-Zionism points out this paradox and demands that the state will become a democracy, subjecting its Jewish nature to the precepts of democratic rule. Neo-Zionism points out this paradox and demands that the state will be first Jewish and only then democratic.

However, from the Zionist perspective, both the neo-Zionists and the post-Zionists see the current situation as unsustainable and absurd. NeoZionism is not shattered by the revelations of post-Zionist historical research, it is in fact premised on embracing them, though not at all in the way hoped for and envision by the post Zionists.

In 2004, the Historian Benny Morris, publishing a second and extensively updated edition of his seminal work, which in many ways inaugurated post-Zionism, The Birth of the Palestinian Refugee Problem (the first edition published in 1988). The original edition suggested that most of the transgressions against Palestinian civilians as well as the expulsion of Palestinian populations during the war emerged from local conditions and initiatives, mostly unknown to (let alone premeditated by) the central high command and leadership. In the second 2004 edition however, Morris corrected this prior picture, pointing out greater involvement of the leadership in the expulsions that were now suggested as more extensive, systematic and to some extent even premeditated. Morris also argued that various Palestinian leaders did encourage certain populations to flee, promising their return once the Zionist forces are defeated. ${ }^{31}$

On the occasion of the publication of the new edition, Morris, in a widely read and discussed interview, argued that the vast uprooting and expulsion of Palestinian populations during the war was necessary for the establishment of a Jewish state. More so, in his opinion, Ben Gurion should have used the (presumably unrepeatable) opportunity to cleanse the entire territory - from the river Jordan to the Mediterranean - and stabilize the state of Israel for generations. ${ }^{32}$

Morris, in systematically unearthing the facts of the uprooting and expulsion of the Palestinian populations in 1948 only to pronounce it not only necessary but also unfortunately partial, embodied the neo-Zionist turn. Unlike the original Zionist position in which the Nakba was originally denied and its remnants actively erased, or the contemporary Zionist hesitant attempts to deny Israeli responsibility to the matter without denying its occurrence, Morris suggests a bluntly unapologetic approach. ${ }^{33}$

Morris' specific version of neo-Zionism may be interpreted as an 
inversed version of the post-Zionist framework Ram termed post-Ideological. Instead of renegotiating the boundaries and identity of the nation by means of owning up, apologizing and compensating, past transgressions, Morris calls on the Israeli public acknowledge what has happened but without empathy or remorse. The renegotiated nation preferred by Morris is not multi-ethnic (it is multi-cultural with regard to the various Jewish cultures) but mono-ethnic. Its boundaries and identity are indeed renegotiated by means of coming to terms with the nation's history, for example the regretful reluctance to cleanse the entire land of Israel in 1948.

However, there are other noteworthy variations of neo-Zionism. For example the Shalem Center - a private neo-conservative think tank and academic press that recently opened the first private Israeli liberal arts college - has developed and disseminated since its foundation in 1994, a myth cultivating and affirming the approach. Following the philosophy of Leo Strauss, the mythical foundation of the political community is regarded as unavoidable and necessary. The practice of debunking national myths - the heart of post-Zionist scholarship - should hence be regarded as both trivial and unacceptably harmful. More so, the debunking of national myths would never lead in some subsequent stage to a grounding of the political community in historical truth, which is both unattainable and unsuitable for the purpose. The creation of new national myths would soon turn out to be unavoidable. Given so, this type of neo-Zionism, suggest embracing and cultivating national myths rather than slaying holy cows.

In 2009, (the English translation was published in 2011,) the historian Boaz Neumann published what is probably the best example of this type of neo-Zionist historiography. The book, titled Land and desire in early Zionism, ${ }^{34}$ attempts to reconstructs the language and imagery of Zionist pioneers, carefully imitating them so as to speak from within their emotionally flooded experience. The group studied was in reality a small minority and has been already grossly over-represented and mythologized in Zionist historiography. Neumann's depiction of their life as continuously bordering on the verge of ecstasy, is rather unlikely and is based on the fact that they tended to use poetic hyperbolic language in their letters and memoirs. However, Neumann is not trying to write a social history of Jewish colonisation in Palestine at the early decades of the twentieth century. His book revamps the Zionist pioneering myth by means of reconstructing their myth making voice - their experience in the moments when they happened to actually be enchanted, rather than disenchanted and bitter.

\section{Conclusion}

In view of the publication of two comprehensive histories of the post-Zionist movement in Israel during the 1990s, by two of the leading scholars associated with post-Zionism, the historian Ilan Pappe and the sociologist Uri Ram, I tried 
in this article to outline what is - or in my opinion should be - at stake in writing such a history. Reading Ram's and Pappe's studies against the background of Silberstein 1999 study, which up until now was the best available source in English for those interested in post-Zionism, I reviewed the different postZionist approaches or frameworks.

I argued that the category of neo-Zionism, which both Pappe and Ram suggest as the current ideological mood in Jewish Israeli society, should be better distinguished from classic Zionism. Pappe seems to actually think that there is no meaningful difference between Zionism and neo-Zionism, albeit the chronological fact that neo-Zionism came after the demise of the post-Zionist challenge, which he believed (and with good reason) failed. However, his use of the category then appears questionable. Ram on the other hand clearly distinguishes between neo-Zionism and Zionism, which is in his case less of a challenge given that he argues that post-Zionism, though defeated in terms of political and popular adherence, did restructure Israeli discourse in an irreversible way. However, I argued that Ram fails to convince that neo-Zionism is not in fact part of the post-Zionist family at its core. Seen from the Zionist perspective, both ideological developments reject the basic Zionist premise of a Jewish-democratic state, though the post-Zionist advocate subjecting the Jewish element to the democratic nature of the state while the neo-Zionist appear to actually currently succeed in subjecting the state's democratic pretenses to its Jewish nature.

By acknowledging that neo-Zionism is part of the post-Zionist turn, we would be able to better analyze the nature of the ideological transformations in Israeli Society since the late 1980s. The de-nationalization that was what we commonly call post-Zionism was followed by a re-nationalization in the form of neo-Zionism. Given the high hopes for the emergence of an inclusive and multicultural democracy in Israel, during the 1990s, the frustration and despair of Pappe and Ram in view of neo-Zionism are understandable. This however does not mean that post-Zionism failed, only that it did not lead to what they hoped it would.

I suggested borrowing the terms de-nationalization and re-nationalization from the South African context. I believe that the demise of Afrikaner nationalism and the subsequent re-nationalization process, in the form of an African nationalism, though very different and far less disappointing (though nevertheless still disappointing) follow a similar pattern to that of the rise and alleged fall of post-Zionism in Israel. It seems to me that we should now turn to study the intellectual history of post-Zionism comparatively as one particular example of a far more general pattern of de-nationalization and re-nationalization. 


\section{NOTES}

1 The Economist, 23 April 1998. http://www.economist.com/node/160777.

2 Jean-Francois Lyotard, The Postmodern Condition: a Report on Knowledge, (Minneapolis: University of Minnesota press, 1984); Jurgen Habermas, The PostNational Constellation (Cambridge: MIT Press, 2001 - original German edition 1998); Richard Rorty, Contingency Irony and Solidarity (Cambridge: Cambridge University Press, 1989).

${ }^{3}$ Floors A. Van Jaarsveld, Lewende verlede (Johannesburg: Afrikaans Pers-boekhandel, 1961); see also Hermann Giliomee, The Afrikaners, (Cape Town: Tafelberg, 2003), 165-166.

${ }^{4}$ See the description of the incident in the South African Truth and Reconciliation Committee's final report, volume 6 chapter 3 section 9 subsection 9, 460. (http://sabctrc.saha.org.za/reports/volume6/section3/chapter6/subsection9.htm - accessed 13 October 2014); see the detailed analysis in: Arthur Kemp, Victory or Violence the story of the AWB of South Africa (Pretoria: Ostara Publications, 2012), Chapter Two.

${ }^{5}$ For the debate about whether Afrikaner nationalism is dead or not see: Marianna Kriel, "A new generation of Gustav Prellers? The Fragmente/FAK/Vrye Afrikaan Movement, 1998-2008," African Studies 713 (2012 ): 447-66; Yehonatan Alsheh and Florian Eliker, "The Art of Becoming a Minority: Afrikaner Re-politicization and Afrikaans Political Ethnicity" African Studies (forthcoming)

${ }^{6}$ A wonderful example of the way the history of the South African war is currently being written is Bill Nasson, The War for South Africa, (Cape Town: Tafelberg, 2010); more specifically the way the history of the concentration camps of the war is now written: Elizabeth Van Heyningen, Concentration Camps of the Anglo-Boer War - a Social History (Auckland: Jacana press, 2013).

${ }^{7}$ See in Herman Giliomee, The Last Afrikaner Leaders - A Supreme Test of Power, (Cape Town: Tafelberg, 2010), 11.

8 A good example for the current results of this very much ongoing process is Herman Giliomee and Bernard Mbenga (eds.), New History of South Africa (Cape Town: Tafelberg, 2007).

${ }^{9}$ Blaser, T. M., "A New South African Imaginary: Nation Building and Afrikaners in Post-Apartheid South Africa," South African Historical Journal, 51, (2004): 179-181; Blaser, T. M. and Van der Westhuizen, C., "Introduction: The Paradox of Post- Apartheid 'Afrikaner' Identity: Deployments of Ethnicity and Neo-Liberalism," African Studies, 71.3 (2012): 380-390; Davies, R., Afrikaners in the New South Africa. Identity Politics in a Globalized Economy, (London: I. B. Tauris, 
2009); Davies, R., "Rebuilding the Future or Revisiting the Past? Post-Apartheid Afrikaner Politics" Review of African Political Economy, 34.112 (2007:. 353-370. 10 Gillian Hart, Rethinking the South African Crisis, (Athens: University of Georgia press, 2014), chapter 4.

11 The best being: Ran Greenstein, Genealogies of Conflict - Class Identity and State in Palestine/Israel and South Africa (London: Wesleyan University Press, 1995); Mona Y. Younis, Liberation and democratization - the South African and Palestinian National Movements (Minneapolis: University of Minnesota Press, 2000). 12 For example: Card, C., "Genocide and social death," Hypatia, 18.1 (2003): 6379 .

13 The classic proponents of the modernist approach are: Gellner, E., Nations and Nationalism, (Oxford: Blackwell, 1983); Hobsbawm, E., Nations and Nationalism since 1780: Program, Myth, Reality, (Cambridge: Cambridge University Press, 1991) and Anderson, Imagined Communities: Reflections on the Origins and Spread of Nationalism, (London: Verso, 1983); The opposite primordial thesis is Smith, A., The Ethnic Origins of Nations, (Oxford: Blackwell, 1986); Smith, A., Nationalism and Modernism: A Critical Survey of Recent Theories of Nations and Nationalism, (London: Routledge, 1998); Smith, The Antiquity of Nations, (Cambridge: Polity, 2004); Smith, A., Ethno-Symbolism and Nationalism, (London: Routledge, 2009); a good contemporary synthesis is: Gat, A. and Yakobson, A., Nations - The Long History and Deep Roots of Political Ethnicity and Nationalism, (Cambridge: Cambridge University Press, 2013).

14 Kwame Anthony Appiah, In My Father's House: Africa in the philosopby of culture, (Oxford: Oxford University Press, 1992), 45.

15 The historian Shlomo Sand stressed in this regard the institutional framework - first and foremost the separation of historiographical research in Israeli academia into departments of Jewish History and departments of so-called "General History" (each with its own professional journals and associations) - as being an unsurmountable obstacle to post-Zionism. Shlomo Sand, "Post-Zionism: A Historiographical or Intellectual Debate?" in: Sand, The Words and the Land, (Los Angeles: Semiotext - MIT University Press, 2007), 155-180.

16 See for example: Mark Gibney, Rhoda E. Howard-Hassmann, Jean-Marc Coicaud, and Niklaus Steiner (eds.), Age of Apology, (Philadelphia: University of Pennsylvania press, 2007).

17 See in this regard Mark Mazower discussion in Governing the World, (New York: Penguin, 2012) and also Marta C. Nussbaum, Political Emotions (Cambridge: Harvard University Press, 2013).

18 Daniel Gutwein, "Left and Right Post-Zionism and the Privatization of Israel's Collective Memory," in: A. Shapira \& D. Penslar eds., Israeli Historical Revisionism: From Left to Right, (London: Frank Cass, 2001), 9-42; “The 
Privatization of the Holocaust: Memory, Historiography and Politics." Israel studies, 41(1) 2009, 36-64.

19 R. Brubaker, "Ethnicity without groups," Archives Européennes de Sociologie, 42.2 (2002): 163-89; "In the name of the nation," Citizenship Studies, 8.2 (2004): 11527; "Ethnicity, race, and nationalism," Annual Review of Sociology 35 (2009): 21-42; "Religion and nationalism: four approaches," Nations and Nationalism, 18.1 (2012): 2-20.

20 See in this regard Yifat Weiss study, Wadi Salib (Jerusalem: Van Lir, 2007)[in Hebrew] - one the finest examples of post-Zionist historiography. Unfortunately still unavailable in translation.

21 Shlomo Sand, The Invention of the Jewish People (London: Verso, 2009) the book was followed by the Invention of the Land of Israel (London: Verso, 2012) and How I Stopped Being a Jew (London: Verso, 2013). See for example Anita Shapira's polemics against Sand in: "Review Essay: The Jewish-people deniers," The Journal of Israeli History, Vol. 28, No. 1, March 2009, 63-72.

22 Adi Ophir and Ariela Azoulay, The One State Condition: Occupation and Democracy in Israel Palestine (Palo Alto: Stanford University press, 2012); Azoulay, From

Palestine to Israel: A Photographic Record of Destruction and State Formation, 1947-1950, (London: Pluto Press, 2011).

23 For the project see: http://mafteakh.tau.ac.il/en/.

24 Dafna Hirsch, Hygiene Education and Culture Building in the Jewish Society of Mandate Palestine (Be'er Sheva: Ben Gurion University Press, 2014) [in Hebrew].

25 http://www.haaretz.co.il/magazine/.premium-1.2586941 [in Hebrew].

26 Uri Ram, The Time of The Post-Nationalism and the Politics of Knowledge in Israel (Tel Aviv: Resling Academic Press, 2006) [in Hebrew].

27 Primary sources, i.e. neo-Zionist publications (in distinction from secondary literature analyzing neo-Zionism) available in English are: Yoram Hazony, The Jewish State: the Struggle for Israel's Soul (New York: Basic Books, 2001); Benny Morris, Righteous Victims: A History of the Zionist Arab Conflict, (New York: Vintage, 2001).

28 Uri Ram (ed.), Israeli Society Critical Perspectives, (Tel Aviv: Breirot, 1993) [in Hebrew].

29 Ronen Shoval, Im Tritzu: a star from Israel (Tel Aviv: Reuven Mas, 2010), 12.

30 A good example, written for non-Hebrew readers and especially North American audiences, is Ari Shavit, My Promised Land: the Triumph and Tragedy of Israel (NY: Random House, 2003). Anita Shapira's, Israel - a History (Waltham: Brandeis University Press, 2012) is not explicit in its debate with neo-Zionist (or occasionally post-Zionist) positions, yet is also an example of current old-school Zionist scholarship. 
31 Benny Morris, The Birth of the Palestinian Refugee Problem Revisited (Cambridge: Cambridge University Press, 2004); see also: Correcting a Mistake: Jews and Arabs in Palestine/Israel, 1936-1956, (Tel Aviv: Am Oved Publishers, 2000) [in Hebrew]; Righteous Victims: A History of the Zionist-Arab Conflict, 1881-1999, (New York: Alfred A. Knopf, 2001); and 1948: A History of the First Arab-Israeli War, (New Haven: Yale University Press, 2008).

32 The interview tilted "waiting for the Barbarians" is available at: http://www.haaretz.co.il/misc/1.936900.

33 The best example for a Zionist reading of the Nakba is Yoav Gelber, Independence and Nakba (Tel Aviv: Devir, 2004) [in Hberew] - I think Pappe is wrong to label Gelber a neo-Zionist, he is a rather classic Zionist.

34 Boaz Neumann, Territory and Desire in Early Zionism (Waltham, Massachusetts: Brandeis University Press/University Press of New England, 2011). 